\title{
GeoTAB: Identificação dos biomas e da vegetação na região de atuação da Embrapa Tabuleiros Costeiros
}

\author{
GeoTAB: Identification of biomes and vegetation in the Embrapa Tabuleiros Costeiros' study \\ region
}

\author{
L. R. Nogueira Junior ${ }^{1 *}$; M. H. G. Dompieri ${ }^{1}$; M. A. S. Cruz ${ }^{2}$ \\ ${ }^{1}$ Embrapa Territorial, 13070-115, Campinas-SP, Brasil \\ ${ }^{2}$ Embrapa Tabuleiros Costeiros, 49032-280, Aracaju-SE, Brasil
}

*lauro.nogueira@embrapa.br

(Recebido em 19 de agosto de 2019; aceito em 27 de novembro de 2019)

\begin{abstract}
Conhecer as características fitofisionômicas da vegetação nativa de uma região é fundamental para o planejamento de políticas públicas e programas de conservação e uso sustentável da vegetação, bem como para tomadas de decisões de cunho social, político, jurídico, econômico e ambiental. A região de atuação da Embrapa Tabuleiros Costeiros abrange 21,95 milhões de hectares em sete estados ao longo da costa atlântica do Nordeste brasileiro. Este trabalho teve como objetivo identificar os biomas e o tipo de vegetação dessa região, de acordo com normas do Instituto Brasileiro de Geografia e Estatística (IBGE). As informações foram obtidas a partir de dados do IBGE disponibilizados em 2018 e 2019 no formato vetorial, na escala de 1:250.000, e de dados de publicações técnicas e científicas disponíveis em base de dados digitais e em publicações impressas. A Mata Atlântica (63\%) e a Caatinga (37\%) são os dois biomas presentes na área de estudo. Considerando a vegetação pretérita, as formações vegetais identificadas foram: Floresta com 52,11\%; Savana-estépica com 23,05\%; Áreas de contato com 14,64\%; Áreas de Formações Pioneiras com 4,92\%; Savana com 1,37\%; Campinarana com 0,02\% e áreas indiscriminadas somaram 3,89\%. Em 2017, 77\% da área de estudo estava antropizada, restando apenas $4,14 \%$ de florestas naturais. Considera-se que pesquisas e políticas públicas relacionadas à regularização e fiscalização ambiental devem voltar-se para a preservação dos remanescentes de florestas naturais e a recomposição de florestas nativas em áreas estratégicas dentro dos imóveis rurais do Cadastro Ambiental Rural.
\end{abstract}

Palavras-chave: Mata Atlântica, Caatinga, Agreste.

Knowing the characteristics of the native vegetation of a region is essential for the planning of programs and public policies, particularly in the scope of social, political, legal, economic and environmental decisions. Embrapa Tabuleiros Costeiros' study region encompasses a total of 21.95 million hectares in 7 states along the Atlantic coast in Northeastern Brazil. In this study we aimed to identify the region's biomes and vegetation, in agreement with the Brazilian Institute of Geography and Statistics' (IBGE) directives. We used vector data from IBGE in the scales 1:250,000, and data from technical and scientific publications available in digital databases and in print publications. Atlantic Forest (63\%) and Caatinga (37\%) are the two biomes that cover the study area. Considering the previous vegetation, which was theoretically present before the discovery of Brazil, the vegetation formations identified were: Forest with $52.11 \%$; Savannah-Steep with 23.05\%; Areas of contact with 14.64\%; Pioneering Formation Areas with 4.92\%; Savannah with 1.37\%; Campinarana with $0.02 \%$. Unspecified areas accounted for 4.14\%. In 2017, 77.36\% of Embrapa Tabuleiros Costeiros' study region was located in anthropized areas, leaving only $4.14 \%$ of natural forests. It is considered that research and public policies related to environmental regularization and inspection should focus on the preservation of remnants of natural forests and the restoration of native forests in strategic areas within the rural properties of the Rural Environmental Registry.

Keywords: Atlantic Forest, Caatinga, Agreste.

\section{INTRODUÇÃO}

O termo 'bioma' tem sido usado para definir um espaço geográfico de dimensões subcontinentais cujas características macroclimáticas, geomorfológicas e fitofisionômicas apresentem certo nível de homogeneidade [1]. Devido à demanda por uma representação cartográfica dos biomas no território brasileiro, em 2003, o Ministério do Meio Ambiente (MMA) e o Instituto Brasileiro de 
Geografia e Estatística (IBGE) estabeleceram um entendimento amplo do conceito de bioma [2]. Nesse entendimento, conceituaram o bioma como um conjunto de vida vegetal e animal constituído pelo agrupamento de tipos de vegetação contíguos e identificáveis em escala regional, com condições geoclimáticas similares e história compartilhada de mudanças, resultando em uma diversidade biológica própria. As possíveis correlações entre os biomas brasileiros (Amazônia, Caatinga, Cerrado, Mata Atlântica, Pampa e Pantanal) e os conceitos fitogeográficos, que definiram o Mapa de Vegetação do Brasil [3], constituíram o embasamento técnico operacional do estudo que resultou na produção do Mapa de Biomas do Brasil [2]. No Brasil, os biomas vêm sendo base para o estabelecimento de leis, o planejamento de ações e o direcionamento de recursos para conservação e uso sustentável da biodiversidade, do uso e cobertura da terra, da adaptação e mitigação das mudanças climáticas, de pesquisas técnico-científicas em ciências agrárias e biológicas, entre outros.

Por sua vez, o mapa de vegetação do Brasil [3] representa uma provável reconstituição dos tipos de vegetação que revestiam o território brasileiro antes da chegada dos colonizadores europeus, ou seja, antes de 1.500. Nesse mapa, a provável extensão dos tipos de vegetação, classificados em regiões fitoecológicas e em áreas de vegetação, foi estimada, em primeiro lugar, com base na bibliografia fitogeográfica reconhecida como a mais autêntica e confiável, no levantamento dos remanescentes da vegetação natural e em trabalhos de campo. Assim, o mapa de vegetação do Brasil apresenta as regiões fitoecológicas e as demais áreas de vegetação com os respectivos grupos e subgrupos de formação remanescentes. O mapeamento da vegetação foi baseado em critérios fisionômico-ecológicos, obedecendo a uma hierarquia de formações delimitadas pelos parâmetros dos ambientes ecológicos e esquematizadas segundo uma chave de classificação iniciada a partir de duas grandes classes de formações: florestal e campestre. Recentemente, o IBGE disponibilizou, em sua página na internet [5, 6], o mapa de vegetação e de biomas do Brasil na escala 1:250.000.

A Embrapa Tabuleiros Costeiros, Unidade Descentralizada da Empresa Brasileira de Pesquisa Agropecuária (Embrapa), vinculada ao Ministério da Agricultura, Pecuária e Abastecimento, é uma das 47 Unidades Descentralizadas de Pesquisa da Embrapa. Criada em 1993, com sede em Aracaju, capital do estado de Sergipe, tem suas origens nas antigas Unidades de Execução de Pesquisa de Âmbito Estadual (UEPAE) e no Centro Nacional de Pesquisa de Coco (CNPCo). Além da sede, ela conta com campos experimentais nos municípios de Frei Paulo, Nossa Senhora das Dores, Itaporanga d'Ajuda e Umbaúba, no estado de Sergipe, e com uma Unidade de Execução de Pesquisa e Desenvolvimento (UEP) no município de Rio Largo, no estado de Alagoas. Ela tem como missão "Viabilizar soluções de pesquisa, desenvolvimento e inovação para a sustentabilidade da agricultura nos Tabuleiros Costeiros em benefício da sociedade brasileira".

No ano de 2015, a Embrapa Tabuleiros Costeiros iniciou a execução de um projeto intitulado Organização e disponibilização da informação geoespacial sobre recursos naturais e aspectos socioeconômicos da área de atuação da Embrapa Tabuleiros Costeiros (GeoTAB) [4]. O projeto GeoTAB vem organizando e disponibilizando informações geoespaciais sobre recursos naturais (solo, água, clima e vegetação) e aspectos socioeconômicos de relevância agropecuária e ambiental na base de dados Infraestrutura de dados espaciais da Embrapa (GeoInfo), que possui interface para Web. Os dados e informações geradas pelo projeto GeoTAB visam subsidiar o planejamento e desenvolvimento de ações de pesquisa, desenvolvimento e inovação (PD\&I), bem como a formulação e/ou execução de políticas públicas na região de atuação da Embrapa Tabuleiros Costeiros. Entende-se que a disponibilidade de dados espaciais possa contribuir de forma significativa para a detecção de alterações e de impactos da antropização na região e para o acesso a informações que subsidiem a tomada de decisão de âmbito social, político, jurídico, econômico e ambiental, nas diversas esferas de governo e de setores da sociedade, promovendo maior agilidade nas respostas das instituições frente aos riscos e oportunidades que surjam relacionadas à atividades agropecuárias e meio ambiente.

Nesse contexto, o presente trabalho teve como objetivo identificar quais são os biomas e os tipos de vegetação que ocorrem na região de atuação da Embrapa Tabuleiros Costeiros. 


\section{MATERIAL E MÉTODOS}

A definição dos municípios da região de atuação da Embrapa Tabuleiros Costeiros (área de estudo) foi condicionada aos municípios de ocorrência das unidades da paisagem Tabuleiros Costeiros e Baixada Litorânea [7], e aos municípios adjacentes [8] (Figura 1). Nessa definição foram abrangidos 570 municípios ao longo de sete estados (BA, SE, AL, PE, PB, RN e CE), sendo que 347 estão total ou parcialmente contidos nos Tabuleiros Costeiros e na Baixada Litorânea, e os 223 restantes estão em áreas adjacentes. Além dos Tabuleiros Costeiros e da Baixada Litorânea, mais 12 unidades da paisagem compõem a área de estudo, com destaque para as Superfícies Retrabalhadas e a Depressão Sertaneja [7]. A área político-administrativa dos Tabuleiros Costeiros e da Baixada Litorânea equivale a aproximados 15,3 milhões de hectares, e aquela representativa das áreas adjacentes corresponde a 6,6 milhões de hectares, totalizando 21,95 milhões de hectares ao longo da costa atlântica do Nordeste do Brasil.

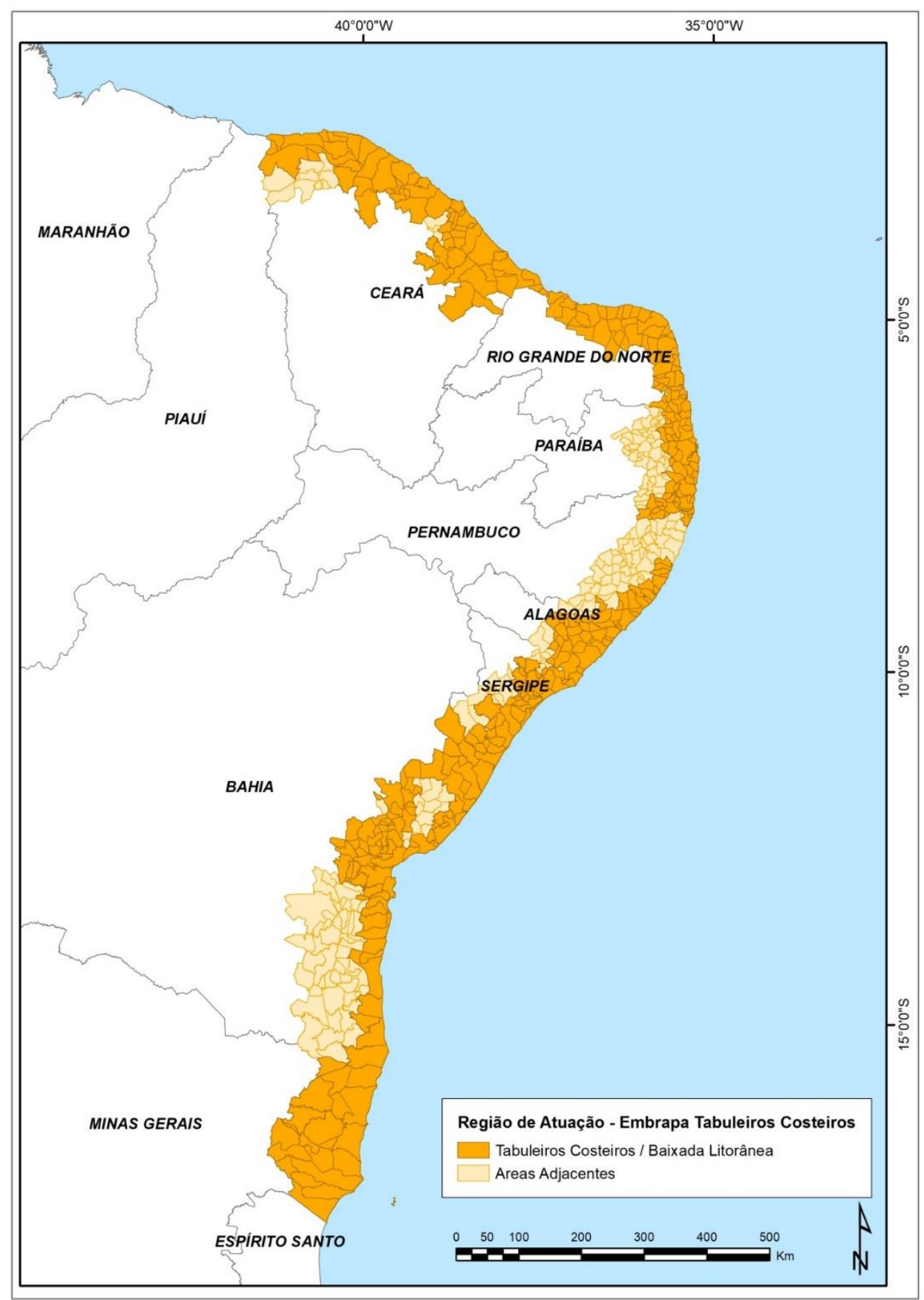

Figura 1: Limites geográficos dos municípios e estados da região de atuação da Embrapa Tabuleiros Costeiros. 
$\mathrm{Na}$ área de estudo ocorre o clima tropical que varia de úmido a subúmido. As temperaturas anuais médias variam em torno de $26^{\circ} \mathrm{C}$, e há pouca diferença entre as médias do mês mais quente e as do mês mais frio [7]. O regime de chuvas é bastante distinto em função da localização da área ao longo da costa atlântica, tanto em termos de latitude quanto de longitude. A média da precipitação anual varia de $400 \mathrm{~mm}$ a $2.300 \mathrm{~mm}$, e a distribuição das chuvas durante o ano é variável. Quanto à precipitação, a área de estudo foi caracterizada em quatro regiões [4]: $1^{\text {a }}$ ) da divisa entre os estados Bahia e Espírito Santo até a cidade de Valença-BA, com precipitação média anual em torno de $1.300 \mathrm{~mm}$ e $2.300 \mathrm{~mm}$ e período de chuvas ocorrendo entre novembro e julho; $2^{\mathrm{a}}$ ) da cidade de Valença-BA até o rio São Francisco, com precipitação média anual em torno de $1.050 \mathrm{~mm}$ e 1.850 $\mathrm{mm}$ e período de chuvas ocorrendo entre março e setembro; $3^{\mathrm{a}}$ ) do rio São Francisco até a cidade de Touros-RN, com precipitação média anual em torno de $1.200 \mathrm{~mm}$ e $2.300 \mathrm{~mm}$ e período de chuvas ocorrendo entre fevereiro e setembro; $4^{\mathrm{a}}$ ) da cidade de Touros-RN até a divisa dos estados Ceará e Piauí, com precipitação média anual em torno de $400 \mathrm{~mm}$ e $1.600 \mathrm{~mm}$ e período de chuvas ocorrendo entre janeiro e julho. Os solos dos Tabuleiros Costeiros, principal unidade da paisagem da área de estudo, destacam-se pelos horizontes subsuperficiais coesos, associados ao baixo teor de $\mathrm{Fe}$, Si e Al. O solo coeso é entendido como horizonte pedogenético adensado, muito duro ou extremamente duro quando seco e normalmente friável quando úmido [9]. Já na Baixada Litorânea, segunda maior unidade da paisagem da área de estudo, ocorre grande predominância de Neossolos Quartzarênicos.

Esse estudo foi desenvolvido por meio da estruturação e análise de dados secundários no formato vetorial. Os dados analisados da área de estudo, tanto dos biomas identificados quanto da vegetação, têm como fonte o IBGE [5, 6] e estão disponíveis na escala de 1:250.000.

Os tipos de vegetação identificados incluem a vegetação pretérita, aquela vegetação teoricamente existente antes do descobrimento do Brasil, e a vegetação dominante, conforme a tabela de atributos dos dados vetoriais do IBGE [5]. O Manual Técnico da Vegetação Brasileira [10] serviu de base para a descrição dessas vegetações. Além disso, nessas descrições foram apresentados dados de pesquisas técnico-científicas disponíveis em bases de dados digitais (Web of Science; Scopus; Scielo; Ministério do Meio Ambiente) e em publicações impressas, tendo como palavras chave termos relacionados a vegetação: florística, fitossociologia, plano de manejo, flora entre outros. Dessa busca de literatura consideraram-se alguns estudos florísticos e fitossociológicos de remanescentes florestais e de planos de manejo de unidades de conservação da natureza realizados em municípios integrantes da região de atuação da Embrapa Tabuleiros Costeiros. Na apresentação dos dados de literatura apontou-se a regionalidade, municipalidade, coordenadas geográficas e algumas características da vegetação, como estrutura florestal e florística, apresentando-se as principais famílias, gêneros e espécies.

\section{RESULTADOS E DISCUSSÃO}

\subsection{Biomas}

A Mata Atlântica e a Caatinga são os dois biomas que abrangem a área de estudo - região de atuação da Embrapa Tabuleiros Costeiros (Figura 2). A Mata Atlântica cobre 13.195.232 ha $(62,82 \%)$ e a Caatinga 7.808 .640 ha $(37,18 \%)$.

\subsubsection{Mata Atlântica}

No contexto nacional, a Mata Atlântica ocupa aproximadamente 131 milhões de hectares do território brasileiro em 3.222 municípios, onde vivem mais de $60 \%$ da população brasileira. Tratase da quarta área entre as oito áreas mais "quentes" em termos de plantas endêmicas, vertebrados endêmicos, relação plantas endêmicas/área (espécies por $100 \mathrm{~km}^{2}$ ), relação vertebrados endêmicos/área (espécies por $100 \mathrm{~km}^{2}$ ) e vegetação primária remanescente em \% da extensão original [11]. Além de apresentar cerca de 20 mil espécies vegetais, abriga cerca de 1.360 espécies da fauna brasileira, com aproximadamente 260 espécies de mamíferos, 620 de aves, 200 de répteis e 280 de anfíbios, sendo que mais de 560 espécies só ocorrem neste bioma [12]. Todavia, é o bioma 
brasileiro mais ameaçado quanto à cobertura de vegetação nativa, restando cerca de $12,4 \%$ de sua cobertura florestal original [13].

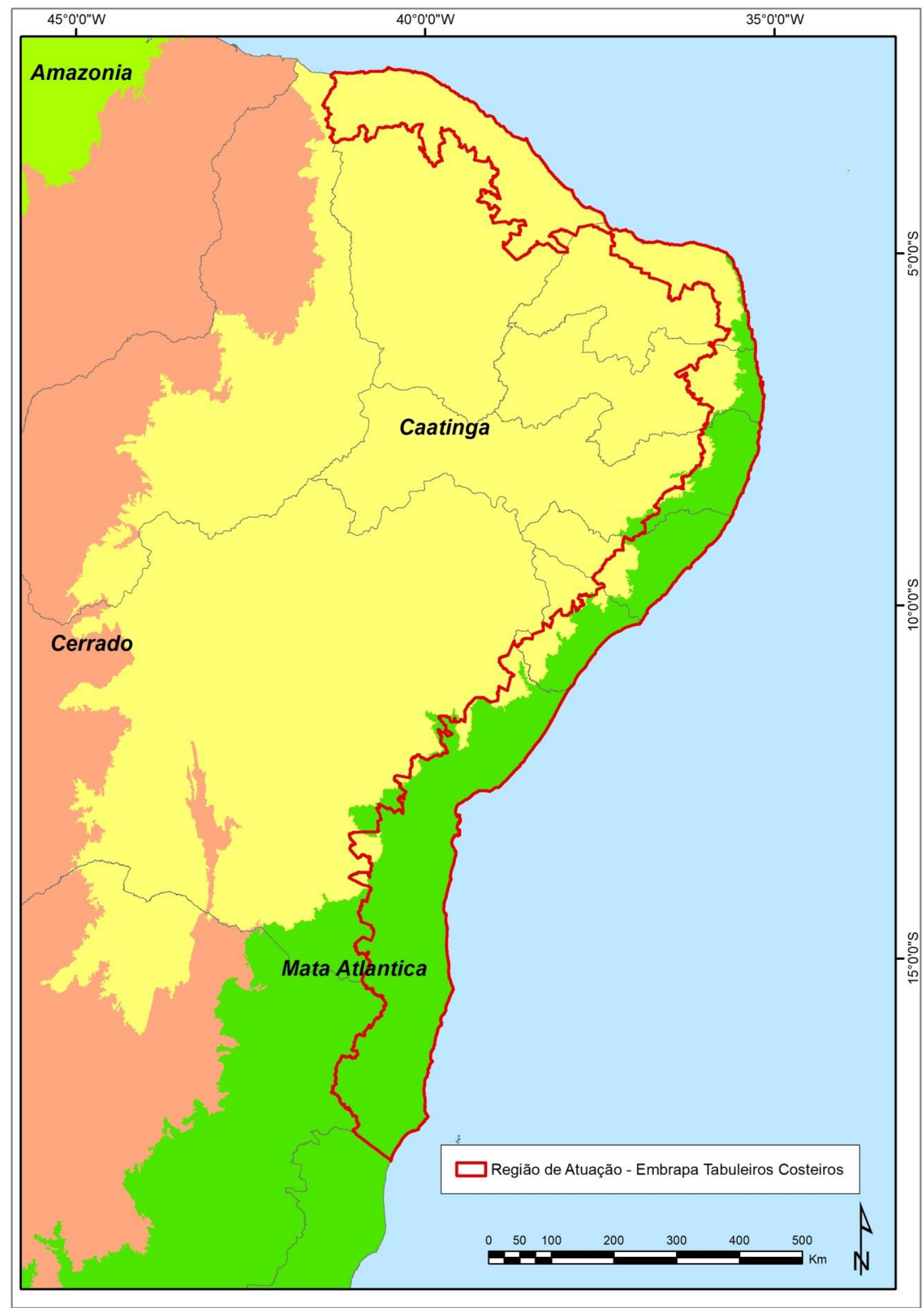

Figura 2: Biomas na região de atuação da Embrapa Tabuleiros Costeiros. Fonte: IBGE (2019) [6]. 
No contexto regional, a Mata Atlântica no sul da Bahia destaca-se como uma região de megadiversidade, um hotspot da biodiversidade brasileira e mundial, e um dos mais importantes centros de endemismo da Mata Atlântica [14]. Ostroski et al. (2018) [15] estudaram uma grande região de Mata Atlântica, que vai do município de Jaguaré, no litoral norte do Espírito Santo, até o município de Entre Rios, no litoral norte da Bahia, e apresentaram 547 espécies de angiospermas endêmicas, distribuídas em 69 famílias, incluindo também sete gêneros endêmicos: Bahiella (Apocynaceae), Santosia (Asteraceae), Harleyodendron (Fabaceae), Cubitanthus (Linderniaceae), Anomochloa e Parianella (Poaceae), e Andreadoxa (Rutaceae). As famílias com mais espécies endêmicas foram Bromeliaceae (108), Fabaceae (41) e Myrtaceae (32).

Associada ao clima quente e úmido costeiro, a Mata Atlântica depende de grande volume e uniformidade de chuvas, e tem como vegetação nativa predominante a Floresta. Na área de estudo, ela ocorre ao longo da costa atlântica, do município de Touros, no litoral norte do Rio Grande do Norte, até o extremo sul da Bahia, na divisa com o Espírito Santo, e incorpora cadeias de montanhas, vales, platôs e planícies em um processo histórico de expansão de formações florestais sobre as campestres, particularmente do Leste para o Oeste.

\subsubsection{Caatinga}

O bioma Caatinga - termo originário do tupi-guarani que significa mata branca - embora esteja localizado em área de clima semiárido, apresenta grande variedade de paisagens, relativa riqueza biológica e espécies exclusivas, com várias tipologias vegetais [16, 17]. A vegetação mais importante é a Savana-Estépica, que apresenta fisionomia decidual e espinhosa, com muitas cactáceas e bromeliáceas, influenciada por baixa pluviosidade, altas temperaturas e luminosidade tropical.

A área mais representativa, o "core" do bioma Caatinga, compreende o Sertão Árido Nordestino, de clima frequentemente marcado por dois períodos secos anuais, um longo, seguido de chuvas intermitentes, e outro curto, com chuvas torrenciais inconstantes, que chegam a faltar por vários anos. Os contrastes fisionômicos são muito acentuados entre a estação chuvosa e a estação seca, com variações de um local para o outro e no mesmo local, conforme a estação do ano. Em uma época a vegetação está sem folhas, em outra época está coberta pelo verde da enorme quantidade de folhas das ervas e da abundante ramificação dos arbustos e das árvores. Esta paisagem só é interrompida em poucas situações, principalmente pela presença de formações florestais (deciduais e/ou semideciduais) e de Savana, associada a ambientes especiais como áreas serranas, brejos e outros tipos de bolsões climáticos mais amenos. Na área de estudo, a Caatinga tem maior ocorrência nos estados do Ceará, Rio Grande do Norte e da Paraíba (Figura 2).

\subsection{Vegetação}

Nos biomas, cada região fitoecológica ou fitofisionomia (Figura 3), as quais serão descritas a seguir, repete suas formas de vidas fenotípicas nos ambientes semelhantes, além das áreas de contato. Estes espaços ecológicos, por sua vez, não são contínuos, e sofrem interrupções em função da disponibilidade de água para as plantas, que refletem as características dos solos e dos tipos de climas que modelaram o relevo. Com base nesses critérios, a região fitoecológica pode ser conceituada como um espaço definido por uma florística de gêneros típicos e de formas biológicas características que se repetem dentro de um mesmo clima, e pode ocorrer em terrenos de litologia variada, mas com relevo bem marcado [10]. 


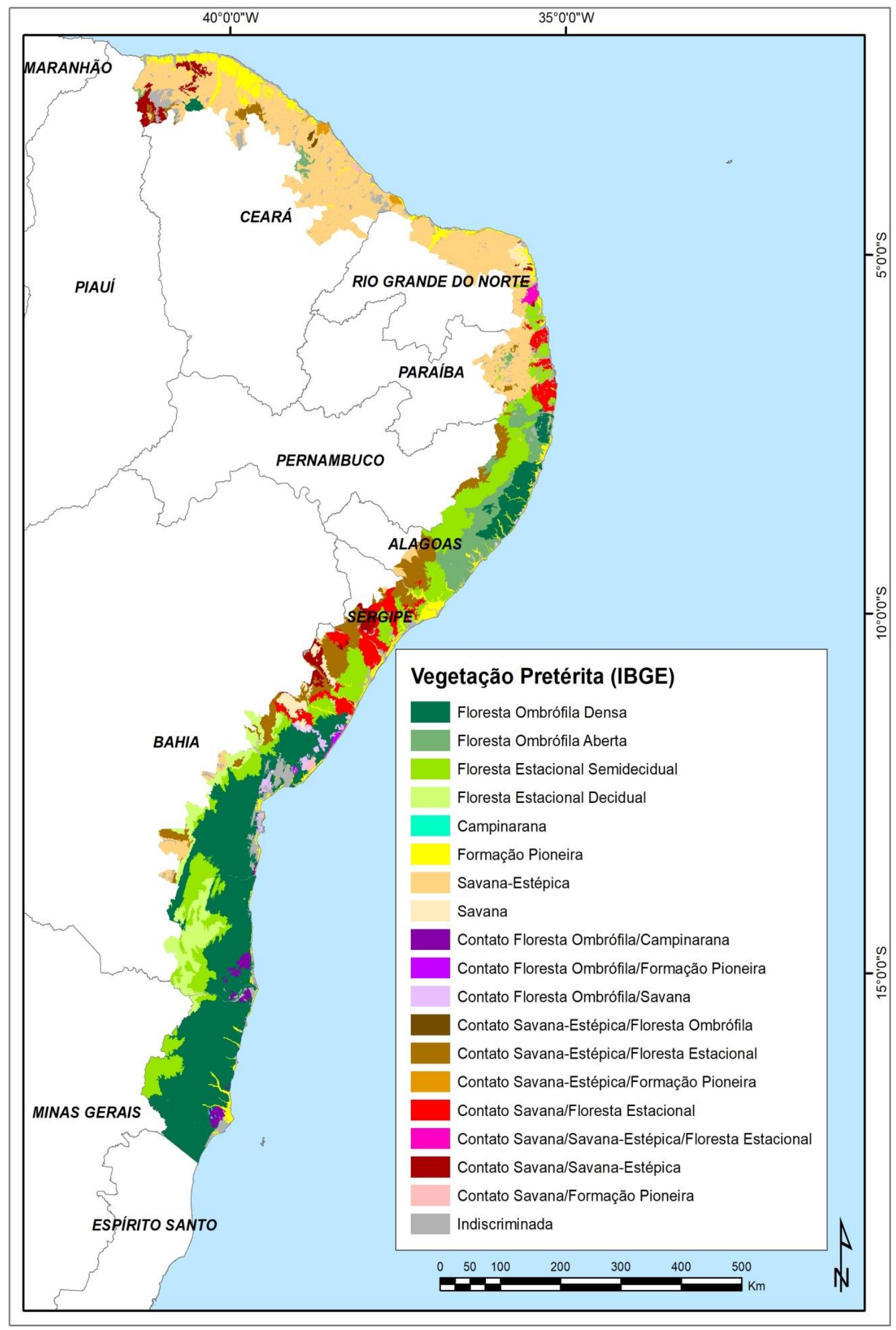

Figura 3: Ocupação da vegetação teoricamente existente no ano de 1.500 na região de atuação da Embrapa Tabuleiros Costeiros. Fonte: IBGE (2018) [5]. 


\subsubsection{Floresta Ombrófila}

A Floresta Ombrófila ocorre em regiões de clima ombrófilo, e é encontrada em locais que apresentam até três meses de umidade escassa durante o ano ou em locais sem período biologicamente seco [10]. Geralmente, a presença dessa formação vegetal é sustentada por chuvas orográficas e/ou água edáfica. Considerando a vegetação pretérita, a Floresta Ombrófila (densa + aberta) cobre 6.982.857 ha (32,33\%) da área de estudo (Tabela 1 e Figura 3).

Tabela 1: Área (ha = hectares e \% = porcentagem) das fitofisionomias da região de atuação da Embrapa Tabuleiros Costeiros.

\begin{tabular}{lrr}
\hline Fitofisionomias $^{\mathbf{1}}$ & ha & $\mathbf{\%}$ \\
\hline Floresta Ombrófila Densa & 5.955 .144 & 27,57 \\
Floresta Ombrófila Aberta & 1.027 .713 & 4,76 \\
Floresta Estacional Semidecidual & 3.232 .492 & 14,97 \\
Floresta Estacional Decidual & 1.039 .558 & 4,81 \\
Campinarana (Muçununga) & 3.969 & 0,02 \\
Formação Pioneira (fluvial, fluviomarinha e marinha) & 1.063 .435 & 4,92 \\
Savana-Estépica & 4.978 .708 & 23,05 \\
Savana & 295.422 & 1,37 \\
Contato Floresta Ombrófila/Campinarana & 155.162 & 0,72 \\
Contato Floresta Ombrófila/Formação Pioneira & 31.021 & 0,14 \\
Contato Floresta Ombrófila/Savana & 153.529 & 0,71 \\
Contato Savana-Estépica/Floresta Ombrófila & 191 & 0,00 \\
Contato Savana-Estépica/Floresta Estacional & 1.398 .196 & 6,47 \\
Contato Savana-Estépica/Formação Pioneira & 65.801 & 0,30 \\
Contato Savana/Floresta Estacional & 839.669 & 3,89 \\
Contato Savana/Savana-Estépica/Floresta Estacional & 49.298 & 0,23 \\
Contato Savana/Savana-Estépica & 424.339 & 1,96 \\
Contato Savana/Formação Pioneira & 46.179 & 0,21 \\
Indiscriminada & 839.518 & 3,89 \\
TOTAL & 21.599 .342 & 100,00 \\
\hline
\end{tabular}

${ }^{1}$ Fonte IBGE (2018) [5], escala 1:250.000, vegetação pretérita.

\subsubsection{Floresta Ombrófila Densa}

A Floresta Ombrófila Densa representa o "core" do bioma Mata Atlântica (Tabela 1 e Figura 3), abrangendo duas grandes áreas, uma que vai da divisa entre os estados Espírito Santo e Bahia, até o município de Conde, no litoral norte da Bahia, e outra denominada de Zona da Mata, que vai do município de Paripuera, no litoral norte de Alagoas, até a divisa dos estados de Pernambuco e Paraíba (Figura 3). É representada principalmente pela Floresta Ombrófila Densa das Terras Baixas (5 m-100 $\mathrm{m}$ de altitude).

No sul da Bahia, a Floresta Ombrófila Densa apresenta dossel alto e denso, com árvores de fuste reto e cilíndrico que podem atingir $40 \mathrm{~m}$ de altura, como Parkia pendula (Willd.) Benth. ex Walp., Caryocar edule Casar., Hydrogaster trinerve Kuhlm., Ecclinusa ramiflora Mart., Virola sp., Sloanea sp., Lecythis lurida (Miers) S. A. Mori e Eriotheca macrophylla [18, 19]. As árvores não se distribuem homogeneamente na floresta, sendo raras em certos pontos e adensadas em outros. Por via de regra, apresenta estratificação bem definida, latifoliada, sempre-verde e com muitas espécies. O sombreamento do sub-bosque é promovido pela cobertura densa e uniforme do dossel, fazendo com que o estrato inferior seja bastante rareado em número de espécies. No sub-bosque, poucas espécies arbóreas chegam até $10 \mathrm{~m}$ de altura, com destaque para Paypayrola blanchetiana Tul., Eugenia flamingensis O. Berg, sendo Myrtaceae e Rubiaceae as famílias mais representativas nesse estrato. As hemiepífitas e epífitas são bem representadas, especialmente pela família Araceae e por representantes do grupo das samambaias. Nessas florestas foi observada a maior proporção de espécies dotadas de diásporos com características associadas à dispersão por animais. Conforme 
o plano de manejo do Parque Nacional do Pau Brasil, o diâmetro médio das árvores nessa área foi de 8,34 cm $( \pm 9,8)$, sendo que os maiores diâmetros foram observados em Manilkara salzmannii (A. DC.) H. J. Lam $(160 \mathrm{~cm})$, Licania hypoleuca Benth. $(96 \mathrm{~cm})$ e Parkia pendula (Willd.) Benth. ex Walp. $(81 \mathrm{~cm})$.

Alguns estudos analisados $[18,19,20,21,22,23,24,25]$ demonstram a alta diversidade de espécies na Floresta Ombrófila Densa, sendo as famílias mais comuns e com maior número de espécies a Fabaceae, Myrtaceae, Rubiaceae, Melastomataceae, Sapotaceae, Apocynaceae. No Parque Nacional do Pau Brasil, situado no município de Porto Seguro, no sul da Bahia, foi identificado 172 espécies em uma área de 0,1 ha [18]. Localizada nesse mesmo município, a RPPN Estação Veracel está entre as dez áreas com maior diversidade de espécies arbóreas por hectare do Brasil [19]. Amorim et al. (2009) [20] identificaram 1.129 espécies em três áreas de floresta na região cacaueira do sul da Bahia. Na Reserva Biológica de Una, Thomas et al. (2008) [21] encontraram 947 espécies de plantas. Na Área de Proteção Ambiental (APA) da Serra Grande, Thomas et al. (2008) [22] registraram 458 espécies de plantas lenhosas em 1 ha. Na RPPN Lontra, localizada nos municípios de Itanagra e Entre Rios, próximos ao litoral norte da Bahia, foram identificadas 210 espécies arbóreas [23]. Na Floresta do Crasto, situada no munícipio de Santa Luzia do Itanhy, no sul do estado de Sergipe, foram identificadas 324 espécies de plantas [24]. Por fim, em um fragmento florestal $\left(07^{\circ} 49^{\prime} \mathrm{S}, 34^{\circ} 59^{\prime} \mathrm{W}\right)$, no munícipio de Igarassu, litoral norte de Pernambuco, Rocha et al. (2008) [25] identificaram 115 espécies arbóreas.

Próximas ao município de Ilhéus, a Reserva Biológica de Una e a Área de Proteção Ambiental (APA) da Serra Grande (14²5'S, 39 $01^{\prime}$ W) são representantes do endemismo de espécies arbóreas na região cacaueira do sul da Bahia [14]. Um pouco mais da metade das espécies - 54,8\% de 420 espécies em Una e 52,3\% de 430 espécies em Serra Grande - não tem distribuição ampla e 7,4\% em cada área são disjuntas entre a Mata Atlântica e a Amazônia [14]. Estudos em Una e Serra Grande apresentaram, respectivamente, $44,1 \%$ e 41,6\% de espécies endêmicas da Mata Atlântica e $28,1 \%$ e $26,5 \%$ endêmicas do sul da Bahia e norte do Espírito Santo [14].

\subsubsection{Floresta Ombrófila Aberta}

Ocupando um total de 1.027.713 ha (4,76\%) na região de atuação da Embrapa Tabuleiros Costeiros (Tabela 1), a Floresta Ombrófila Aberta é composta de árvores espaçadas, com estrato arbustivo pouco denso e caracterizado ora pelas fanerófitas rosuladas, ora pelas lianas lenhosas, e é considerada uma fascinação da Floresta Ombrófila Densa [10]. Ocorre em clima que pode apresentar um período com mais de dois e menos de quatro meses secos, com temperaturas médias entre $24^{\circ} \mathrm{C}$ e $25^{\circ} \mathrm{C}$. Está associada aos bolsões de umidade da costa atlântica nos estados de Alagoas e Pernambuco e das serras interioranas em Alagoas, Pernambuco, Paraíba e Ceará, intercalando-se com outros tipos de vegetação, sobretudo a Floresta Ombrófila Densa e a Floresta Estacional Semidecidual (Figura 3).

Em fragmentos de Floresta Ombrófila Aberta nos municípios de Coruripe, Feliz Deserto e Teotônio Vilela, no sul de Alagoas, Machado et al. (2012) [26] registraram 155 espécies arbóreas de 108 gêneros e 48 famílias. As famílias com mais espécies foram Fabaceae (33), Myrtaceae (15), Sapindaceae (8), Annonaceae (7), Rubiaceae (6) e Apocynaceae, Lauraceae, Lecythidaceae, Moraceae e Sapotaceae (5). Segundo o plano de manejo da Estação Ecológica de Murici [27], situada nos municípios de Flexeiras, Messias e Murici, no norte de Alagoas, a Floresta Ombrófila Aberta caracteriza-se como uma floresta de transição entre a Floresta Ombrófila Densa e a Floresta Estacional Semidecidual, e apresenta maior variação de temperatura e mais dias secos durante o ano.

Considerando a Mata Atlântica do Nordeste brasileiro, uma precipitação anual de no mínimo de $1.600 \mathrm{~mm}$ e um período seco de no máximo dois meses são o que melhor reflete a divisão entre Floresta Ombrófila e Floresta Estacional [21]. Mesmo assim, é preciso considerar a umidade concentrada nos ambientes dissecados das serras e de outros bolsões climáticos. Estudando a composição florística e a estrutura do componente arbóreo de um remanescente florestal de 200 ha $\left(15^{\circ} 12^{\prime} \mathrm{S}, 39^{\circ} 29^{\prime} \mathrm{W}\right)$ ao longo de um transecto de $1.000 \mathrm{~m} \times 10 \mathrm{~m}$ em um gradiente altitudinal entre 350 m e 750 m do nível do mar, na Serra do Teimoso, no munícipio de Jussari, no sul da Bahia, Thomas et al. (2009) [28] constataram a existência de uma transição florística (Leste-Oeste). 
Análises de agrupamento revelaram que a composição florística da floresta situada na porção mais alta do transecto é distinta da floresta na porção mais baixa, e foram classificadas, respectivamente, como Ombrófila Densa e Estacional Semidecidual. Foram identificados e calculados valores de dominância, frequência e de importância para 1.400 indivíduos (árvores e lianas com diâmetro à altura do peito $\geq 5 \mathrm{~cm}$ ), os quais foram agrupados em 264 espécies e 56 famílias de angiospermas. Cariniana legalis (Mart.) Kuntze teve o maior valor de importância, devido à elevada dominância de poucos indivíduos. Discocarpus pedicellatus Fiaschi \& Cordeiro e Ampelocera glabra Kuhlm. foram as espécies mais frequentes, com 90 e 86 indivíduos, respectivamente. Fabaceae, com 37, e Myrtaceae, com 31 espécies, foram as famílias mais diversas.

\subsubsection{Floresta Estacional}

Ocupando um total de 4.272.050 ha (19,78\%) da área de estudo (Tabela 1 e Figura 3), a Floresta Estacional - Semidecidual e Decidual é condicionada por dois períodos climáticos bem distintos, um período de intensas chuvas, com alta umidade, seguido por outro período de estiagem acentuada, com baixa umidade. Rodal et al. (2008) [29] caracterizaram e compararam as Florestas Estacionais do Nordeste oriental brasileiro. A presença/ausência de 248 gêneros de plantas lenhosas em 24 levantamentos florísticos foi correlacionada com a geomorfologia e as variáveis climáticas. As análises apontaram a existência de dois grupos florísticos de Florestas Estacionais, um mais relacionado às florestas litorâneas ao Leste (Mata Atlântica) e outro, às formações xerofíticas ao Oeste (Caatinga), embora possam compartilhar alguns táxons.

\subsubsection{Floresta Estacional Semidecidual}

O conceito ecológico da Floresta Estacional Semidecidual é estabelecido em função da ocorrência de clima estacional, que determina a semidecidualidade da folhagem da cobertura florestal, e tem porcentagem de árvores caducifólias entre 20\% e 50\% [10]. Esta tipologia florestal é constituída por fanerófitos com gemas foliares protegidas da seca por escamas (catáfilos ou pelos) e cujas folhas adultas são esclerófilas ou membranáceas deciduais. É composta por mesofanerófitos, que, em geral, revestem solos areníticos distróficos. Na área de estudo, ocupa um total de 3.232.492 ha (14,97\%), associando-se à região marcada por chuvas de outono/inverno e por acentuada seca no verão, que determina repouso fisiológico e queda parcial da folhagem (Tabela 1 e Figura 3).

Em um levantamento florístico em remanescente de Floresta Estacional Semidecidual ( $11^{\circ} 55^{\prime} \mathrm{S}$, $38^{\circ} 08^{\prime} \mathrm{W}$ ), no município de Entre Rios, próximo ao litoral norte da Bahia, Alves et al. (2015) [30] registraram 192 espécies distribuídas em 139 gêneros e 59 famílias. Das espécies amostradas, 39\% são arbóreas, $31 \%$ são arbustivas, $21 \%$ são trepadeiras herbáceas ou lenhosas, $8 \%$ são ervas e $1 \%$ são epífitas. As famílias com mais espécies foram Fabaceae (18), Rubiaceae (15), Asteraceae (12), Bignoniaceae, Myrtaceae, Sapindaceae (10) e Malvaceae (9). Os gêneros com mais espécies foram Solanum (5), Cupania, Eugenia, Guapira, Myrcia (4), Casearia, Coccoloba, Erythroxylum, Lantana, Myconia, Ocotea, Passiflora, Pavonia, Psychotria, Senna e Serjania (3). A presença de duas espécies novas, uma espécie rara, quatro espécies com distribuição restrita para essa região e duas citadas como vulneráveis demonstra a importância dos remanescentes de Mata Atlântica dessa região, visto que eles contêm riqueza e características fisionômicas não encontradas em outras áreas da Mata Atlântica.

$\mathrm{Na}$ Reserva Biológica Guaribas $\left(06^{\circ} 44^{\prime} \mathrm{S}, 35^{\circ} 09^{\prime} \mathrm{W}\right)$, localizada no munícipio de Mamanguape, estado da Paraíba, a Floresta Estacional Semidecidual apresenta o dossel com altura média de $15 \mathrm{~m}$ a $20 \mathrm{~m}$ e espécies emergentes que podem alcançar até $30 \mathrm{~m}$ de altura [31]. As famílias Sapotaceae, Bignoniaceae, Caesalpiniaceae, Fabaceae, Moraceae e Lecythidaceae, representadas pelas espécies Manilkara salzmannii (A. DC.) H. J. Lam, Tabebuia spp., Apuleia leiocarpa (Vogel) J. F. Macbr, Bowdichia virgilioides Kunth, Brosimum discolor Schott, Ficus spp., Cariniana legalis (Mart.) Kuntze, Lecythis luschnathii O. Berg, entre outras, destacaram-se pelo elevado porte dos indivíduos que foram frequentemente encontrados no interior da floresta, ocupando tanto o dossel quanto o estrato emergente. No dossel da floresta, dominaram Lauraceae, Caesalpiniaceae, Burseraceae, Mimosaceae e Myrtaceae, das quais as mais importantes em densidade as espécies foram Ocotea 
bracteosa (Meisn.) Mez, Caesalpinia echinata Lam., Protium heptaphyllum (Aubl.) Marchand, Protium spruceanum (Benth.) Engl. e Inga blanchetiana Benth., entre outras. O sub-bosque e o estrato herbáceo-arbustivo eram pouco desenvolvidos e formados, principalmente, pelos indivíduos regenerantes de espécies arbóreas, com alturas variando entre $2 \mathrm{~m}$ a $7 \mathrm{~m}$ para o primeiro estrato e chegando até $1 \mathrm{~m}$ para o segundo. Rubiaceae, Myrtaceae e Melastomataceae destacaram-se no subbosque, enquanto, no estrato herbáceo-arbustivo, foram frequentes Cyperaceae e Rubiaceae. Teve destaque a família botânica Erythroxylaceae, em especial o gênero Erythroxylum, que apresentou três espécies nessa região: Erythroxylum passerinum Mart., Erythroxylum rimosum O. E. Schulz e Erythroxylum simonis Plowman [32]. Poucas espécies de epífitas (bromélias e orquídeas) foram verificadas nas áreas em estágio de desenvolvimento secundário, enquanto foi observada alta densidade de epífitas nas formações florestais mais preservadas.

\subsubsection{Floresta Estacional Decidual}

No conceito da Floresta Estacional Decidual varia apenas a intensidade da deciduidade, com mais de 50\% dos indivíduos despidos de folhagem no período de baixa umidade no ar e no solo [10]. O grupo das florestas estacionais mais secas, encontrado sobre os picos elevados da região semiárida e na encosta ocidental do planalto da Borborema, sofre pelo menos oito meses de seca por ano e recebe no máximo $1.000 \mathrm{~mm}$ anuais de precipitação [29]. Este tipo de vegetação ocorre na forma de disjunções florestais e apresenta o estrato dominante macro ou mesofanerófito predominantemente caducifólio. Assim, as formações primárias remanescentes das Florestas Estacionais Deciduais têm dispersão descontínua, ocupam situações geográficas mais interiorizadas, afastadas ou mais abrigadas da influência marítima, e chegam ao contato com a Caatinga. $\mathrm{Na}$ área de estudo, ocupam um total de 1.039 .558 ha $(4,81 \%)$ e compreendem grandes áreas descontínuas, geralmente localizadas de Leste para Oeste entre a Floresta Estacional Semidecidual e a Savana-Estépica (Tabela 1 e Figura 3).

Estudando a fitogeografia e estrutura de dez Florestas Estacionais Deciduais no Brasil, Soares Filho (2012) [33] confirmou a baixa relação florística entre essas florestas, possivelmente causada por grande número de espécies regionalmente endêmicas ou associadas às floras de florestas adjacentes. O padrão de diversidade das dez florestas estudadas e a ampla tolerância aos fatores ambientais corroboraram o caráter ecotonal das florestas analisadas, sendo que a diversidade de média a alta encontrada demonstrou heterogeneidade de habitats e riquezas florísticas. Têm grande ocorrência na Bahia como Floresta Estacional Decidual Submontana e revestem terrenos calcários, com estrutura relativamente alta, conhecida como mata-de-cipó, sempre na forma de disjunções.

\subsubsection{Campinarana}

Considerando o mapeamento da vegetação feito pelo IBGE (2018) [5] e a vegetação pretérita, na área de estudo foram mapeados 3.969 ha de Campinarana. Vale destacar que também foram mapeados 155.162 ha de Campinarana em contato com Floresta Ombrófila Densa (Tabela 1 e Figura 3). Nesses locais, conforme a literatura, ocorre a presença de uma vegetação conhecida regionalmente como Muçununga ou Mussununga [34, 35, 36].

A Muçununga tem sido descrita como um ecossistema associado à Mata Atlântica no sul da Bahia e no norte do Espírito Santo [34, 35, 37]. Nos Tabuleiros Costeiros, a área de ocorrência das Muçunungas caracteriza-se por feições geomorfológicas de interflúvios, que corresponde aos baixos platôs costeiros. Geralmente ocupam Espodossolos e solos transicionais para Argissolos ou Latossolos Amarelos, de textura arenosa, extremamente pobres (oligotróficos), hidromórficos na maioria dos casos, ricos em ácido húmico e fofos. A ocorrência das vegetações de Muçununga tem sido atribuída às características edáficas, as quais são observadas em trechos descontínuos, com formas variadas e em baixas altitudes. Uma característica edáfica é a ocorrência de uma camada de laterita, que causa estresse de inundação na estação chuvosa e estresse hídrico na estação seca. Quanto à vegetação, a Muçununga apresenta predominância de componente arbustivo-herbáceo e um componente arbóreo pouco denso. A diversidade é baixa quando comparada à da Floresta Ombrófila, porém, similar à da vegetação de Restinga. 
A fitofisionomia campestre (Muçununga gramíneo-lenhosa) tem sido relacionada floristicamente à Restinga e apresenta abundância de espécies com folhas esclerófilas perenes e pequenas, e aparência xeromórfica [35]. Para essa fisionomia são descritas duas variantes, a graminoide e a de Bonnetia. A graminoide ocorre nos locais com encharcamento superficial, com menor drenagem do solo, que são locais cobertos principalmente por caméfitos, terófitos e hemicriptófitos das famílias Poaceae, Cyperaceae e nanofanerófitos isolados, representados por Humiria balsamifera (Aubl.) A. St.-Hil. e Baccharis platypoda DC. A de Bonnetia não apresenta encharcamento pronunciado, com solo melhor drenado. São locais dominados por populações de nanofanerófitos da espécie Bonnetia stricta (Nees) Nees \& Mart. sobre termiteiros inativos, os quais formam microssítios de colonização.

A Muçununga arborizada apresenta duas variantes, a aberta e a típica. A aberta é dominada por caméfitos e fanerófitos, e engloba variantes savânicas caracterizadas por nanofanerófitos esparsos, possivelmente providos de xilopódios e tufos do líquen Cladonia sp., refugiados sob a sombra de arvoretas, como as de Hancornia speciosa Gomez. Além dos líquens, foram observadas as espécies de briófitas Helicodontium capillare (Hedw.) A. Jaeger e Haplocladium microphyllum (Hedw.) Broth colonizando o solo desnudo. Populações de caméfitos como Stigmaphyllon paralias A. Juss., fanerófitos como Guapira pernambucensis (Casar.) Lundell, bem como a monilófita Pteridium aquilinum são bem numerosas. A Muçununga arborizada típica é uma formação dominada por caméfitos e fanerófitos. São característicos nanofanerófitos como Humiria balsamifera (Aubl.) A. St.-Hil., Bonnetia stricta (Nees) Nees \& Mart. e Eugenia umbelliflora O. Berg, assim como a microfanerófita Ilex psammophila Mart. ex Reissek. Foram observadas populações numerosas de Guapira pernambucensis (Casar.) Lundell, Gaylussacia brasiliensis (Spreng.) Meisn. e da bromélia Vriesea neoglutinosa Mez. [35].

A Muçununga florestada apresenta florística relacionada à Floresta Ombrófila, sub-bosque de porte baixo e irregularmente aberto, densidade alta de árvores pequenas e finas, escassez de árvores emergentes, e epífitas e lianas abundantes [35]. É composta principalmente por microfanerófitos, e a altura das árvores varia de $7 \mathrm{~m}$ a $20 \mathrm{~m}$, com as copas tocando-se e comumente com mais de uma camada de copas de árvores adultas. A vegetação florestal na Muçununga pode ser associada a locais onde a profundidade do solo é maior e na beira de cursos d'água. As formações "Ilhas com Bromélias" são variantes da Muçununga florestada, com predominância da bromélia Vriesea neoglutinosa Mez, e alternam trechos florestais e campestres.

\subsection{8 Áreas de Formações Pioneiras}

$\mathrm{Na}$ área de estudo, foram mapeados 1.063 .435 ha (4,92\%) de Áreas de Formações Pioneiras, com vegetação de influência fluvial, fluviomarinha e marinha. Essas áreas são compostas por sistemas edáficos de primeira ocupação ao longo do litoral, dos cursos d'água e mesmo ao redor de depressões fechadas que acumulam água, como lagoas e pântanos [10]. Trata-se de áreas pedologicamente instáveis, com sedimentos inconsolidados ou pouco consolidados, sob a influência de diversos processos de acumulação.

\subsubsection{Vegetação com Influência Fluvial}

As áreas de vegetação com influência fluvial, sem referências bibliográficas de destaque para a área de estudo, compreendem comunidades vegetais das planícies aluviais ou de depressões alagáveis, as quais periodicamente refletem os efeitos das épocas chuvosas [10]. Nesses terrenos aluviais, conforme a quantidade de água empoçada e o tempo que ela permanece na área, as comunidades vegetais podem ir desde a pantanosa até os terraços alagáveis temporariamente. Os gêneros Typha, Cyperus e Juncus dominam nas depressões brejosas em todo o País. Nas planícies alagáveis mais bem-drenadas, ocorrem comunidades campestres e os gêneros Panicum e Paspalum dominam em meio ao caméfito do gênero Thalia. Nos terraços mais enxutos, dominam nanofanerófitos dos gêneros Acacia e Mimosa, juntamente com várias famílias pioneiras, como Solanaceae, Asteraceae e Myrtaceae.

\subsubsection{Vegetação com Influência Fluviomarinha}


As áreas de vegetação com influência fluviomarinha (Manguezal e Apicum) compreendem ecossistemas costeiros de ambiente salobro, situados na desembocadura de rios e regatos no mar, na transição entre os ambientes terrestres e marinhos, e estão sujeitos ao regime diário das marés, ocorrendo em estuários, lagunas e planícies de maré [10]. O Manguezal apresenta solo limoso (manguitos), onde cresce uma vegetação especializada e adaptada à salinidade das águas [10]. No Manguezal, podem ocorrer as espécies Rhizophora mangle L., $R$. harrisonii, $R$. racemosa (Rhizophoraceae), Avicennia germinans (L.) Stearn., Avicennia schaueriana Stapf \& Leechm. ex Moldenke (Verbenaceae) e a Laguncularia racemosa (L.) C. F. Gaertn. (Combretaceae) [41]. Nos manguezais pode faltar um ou até dois desses gêneros. Em alguns desses ecossistemas, quando a água do mar fica represada pelos terraços dos rios, a área salobra é densamente povoada por Spartina alterniflora Loisel. e Blutaparon portulacoides (A. St.-Hil.) Mears. (Amaranthaceae), que imprimem ao campo salino o caráter de um manguezal camefítico.

\subsubsection{Vegetação com Influência Marinha}

As áreas de vegetação com influência marinha (restingas e dunas) apresentam variação florística e estrutural, tanto no nível regional quanto local, associadas com a colonização da área a partir de floras adjacentes e a origem geomorfológica dos depósitos arenosos. Nesse sentido, algumas famílias mostraram-se representativas em número de espécies de plantas lenhosas das restingas e dunas do Nordeste, como Fabaceae, Rubiaceae, Melastomataceae e Myrtaceae [38, 39, 40].

Em uma área de Restinga ( $\left(13^{\circ} 09^{\prime} \mathrm{S}, 38^{\circ} 50^{\prime} \mathrm{W}\right)$ no munícipio de Jaguaripe, no estado da Bahia, Costa et al. (2018) [40] identificaram 195 espécies distribuídas em 150 gêneros e 65 famílias. As famílias com mais espécies foram Fabaceae (20), Rubiaceae (19), Melastomataceae (11) e Eriocaulaceae (10). O gênero Myrcia DC. (Myrtaceae) foi o mais diverso, com quatro espécies. Quanto ao hábito, as herbáceas foram as que apresentaram maior número de espécies (90), seguidas por arbustos (61), trepadeiras (24) e arbóreas (20). Diversas espécies são endêmicas da Mata Atlântica, da Restinga ou do estado da Bahia.

Estudando a florística de três tipos de ambientes em restinga da APA de Guadalupe (08 $40^{\circ} \mathrm{S}$, $35^{\circ} 05^{\prime} \mathrm{W}$ ), em Pernambuco, Cantarelli et al. (2012) [39] identificaram 124 espécies distribuídas em 105 gêneros e 57 famílias, 3 delas samambaias. As famílias que apresentaram maior número de espécies foram Myrtaceae (11), Fabaceae (10), Cyperaceae e Rubiaceae (6), Euphorbiaceae, Malpighiaceae e Poaceae (5), Orchidaceae e Solanaceae (4), Asteraceae, Humiriaceae, Lauraceae e Melastomataceae (3), totalizando 55\% das espécies.

\subsection{Savana-Estépica}

A Caatinga abrange as várias formações da Savana-Estépica, que é a denominação de tipologias vegetais campestres, em geral com estrato lenhoso decidual e espinhoso [10]. De caráter estacionaldecidual, essa vegetação apresenta estratos arbóreo e gramíneo-lenhoso periódicos e com numerosas plantas suculentas, sobretudo cactáceas. As árvores são baixas, raquíticas, de troncos delgados e com esgalhamento profuso. Muitas espécies são microfoliadas e outras são providas de acúleos ou espinhos. A maioria das espécies apresenta adaptações fisiológicas bastante especializadas à insuficiência hídrica, assim o endemismo acentua-se no nível das espécies. A distinção entre os subgrupos de Savana-Estépica abaixo apresentados ocorre principalmente dentro de um continuиm estrutural, desde uma fisionomia florestal até uma fisionomia de campo justaposta com moitas ou indivíduos lenhosos isolados. Na área de estudo, a Savana-Estépica abrange 4.978.708 ha $(23,05 \%)$.

\subsubsection{Savana-Estépica Florestada}

A Savana-Estépica Florestada é caracterizada por dossel fechado, estrato superior de $5 \mathrm{~m}$ a $7 \mathrm{~m}$ de altura, predominância de micro e/ou nanofanerófitos, com grossos troncos em geral, profusamente esgalhados, espinhosos ou aculeados, mais ou menos adensados, com total 
deciduidade na época desfavorável [10]. Geralmente apresenta estrato inferior gramíneo-lenhoso, descontínuo e de pouca expressão fisionômica. Com distribuição descontínua, a flora característica pertence, sobretudo, aos gêneros Cavanillesia e Ceiba, da família botânica Malvaceae, Vachellia, Senegalia, Mimosa, Chamaecrista, Caesalpinia e outros da família Fabaceae, e aos gêneros Schinopsis e Astronium, da família Anacardiaceae, em maior número.

\subsubsection{Savana-Estépica Arborizada}

A Savana-Estépica Arborizada é caracterizada por dossel mais esparso, estrato superior arbustivo-arbóreo alcançando $5 \mathrm{~m}$ de altura, geralmente de características semelhantes ao da Savana-Estépica Florestada, descrito acima, e outro estrato inferior gramíneo-lenhoso, de relevante importância fitofisionômica [10]. Na sua composição florística, além de várias espécies do gênero Mimosa, merecem destaque as seguintes espécies endêmicas: Spondias tuberosa Arruda (Anacardiaceae), Commiphora leptophloeos (Mart.) J. B. Gillett (Burseraceae) e Cnidoscolus quercifolius Pohl (Euphorbiaceae), Aspidosperma pyrifolium Mart. (Apocynaceae). Este subgrupo de formação apresenta as mesmas características florísticas da fisionomia ecológica anterior, porém os indivíduos que o compõem são mais baixos.

\subsubsection{Savana-Estépica Parque}

A Savana-Estépica Parque apresenta características fisionômicas muito típicas, com arbustos e pequenas árvores representadas por umas poucas espécies de altura uniforme e distribuição bastante espaçada, como se fossem plantadas [10]. Este subgrupo de formação, associada a áreas alagáveis, recobre geralmente pequenas depressões capeadas por Vertissolos, que, na época das chuvas, são alagadas por não apresentarem boa drenagem. Assim, tem uma distribuição mais restrita e localizada, e apresenta espécies que suportam alagamento periódico. Apresenta pseudo-ordenação de plantas lenhosas raquíticas sobre denso tapete gramíneo-lenhoso de hemicriptófitos e caméfitos. Dominam várias espécies, com destaque para: Mimosa acutistipula (Mart.) Benth. (Fabaceae), Auxemma oncocalyx (Allemão) Baill. (Boraginaceae), Combretum leprosum Mart. (Combretaceae) e Aspidosperma pyrifolium Mart. (Apocynaceae). Estão sempre associados ao capim-panasco, do gênero Aristida.

\subsubsection{Savana-Estépica Gramíneo-Lenhosa}

A Savana-Estépica Gramíneo-Lenhosa, também conhecida como campo espinhoso, apresenta características florísticas e fisionômicas bem típicas, ou seja, extenso tapete graminoso salpicado de plantas lenhosas anãs espinhosas [10]. O terreno é coberto inteiramente pelo capim-panasco (Aristida sp.), espécie hemicriptófita que se apresenta com aspecto de palha na seca e que enverdece na época das águas. Este campo é entremeado de nanofanerófitos espinhosos, despidos de folhagem na seca e cheios de folhas na época das chuvas, pertencentes ao gênero Jatropha (pinhão-brabo), da família Euphorbiaceae.

\subsubsection{Savana}

Apesar de apenas a Caatinga e a Mata Atlântica abrangerem a área de estudo (Figura 2), na identificação da vegetação pretérita (Tabela 1 e Figura 3) destaca-se a presença de Savana, vegetação "core" do bioma Cerrado. As Savanas na área de estudo estão associadas ao Grupo de formação Barreiras do Terciário, localizadas nos Tabuleiros Costeiros. Essas savanas ocupam 295.422 ha $(1,37 \%)$ da área de estudo, em algumas regiões entre os municípios de Alagoinhas e Itapicuru, na Bahia, e entre os municípios de São Gonçalo do Amarante e Touros, no Rio Grande do Norte. Também ocorrem em contato ou tensão ecológica com outras formações vegetais em um total de 1.513.014 ha, em quase todos os estados da área de estudo.

Mesmo apresentando algumas similaridades fisionômicas, a Savana e a Restinga não devem ser confundidas, pois são provenientes de formações geológicas diferentes, uma do Terciário e outra do Quaternário. Todavia, apesar de distintas, em algumas regiões do Nordeste elas podem ser 
consideradas como um continuum vegetacional composto por espécies adaptadas a solos arenosos, com variados padrões distribucionais. Entretanto, alguns cuidados na identificação dessa região fitogeográfica devem ser tomados, visto que, ao estudar a florística das áreas de Savana sobre Tabuleiros Costeiros no leste da Bahia, próximas ao município de Alagoinhas, Reis (2014) [42] apontou similaridades florísticas com as fisionomias de Restinga e de Mata Atlântica e considerou que, nessa região, as áreas de Savana devem ser tratadas como fisionomias relacionadas à Mata Atlântica.

\subsubsection{8 Áreas de Contato ou Tensão Ecológica}

As áreas de contato ou de tensão ecológica entre vegetações ocorrem quando entre duas ou mais regiões fitofisionômicas existem áreas onde essas floras se contatam, justapondo-se ou interpenetrando-se (Figura 3). As áreas de contato foram identificadas como ecótonos, onde a identidade florística passa a ser no nível das espécies, e não há determinação de dominância de uma região sobre a outra, mas frequentemente ocorrem endemismos que melhor as identificam. Já as áreas de tensão ecológica são, às vezes, coincidentes com o contato de duas formações geológicas e com faixas de transição climática, como o Agreste.

Um exemplo de área de tensão ecológica é a região do Parque Nacional da Serra de Itabaiana $\left(10^{\circ} 45^{\prime} \mathrm{S}, 37^{\circ} 20^{\prime} \mathrm{W}\right)$, o qual está inserido nos municípios de Areia Branca, Campo do Brito, Itabaiana, Itaporanga D'Ajuda e Laranjeiras, no estado de Sergipe. O parque está situado em uma área de transição entre a Mata Atlântica e a Caatinga, regionalmente e localmente considerada como Agreste. Um estudo florístico [43] desenvolvido no parque entre 2006 e 2009 apresentou 552 espécies distribuídas em 99 famílias de angiospermas e 1 família de gimnosperma. Das espécies apresentadas, 187 ocorreram na fisionomia arbustiva-herbácea, 304, na arbustiva e 247, na arbórea, sendo 23 comuns a todas as fisionomias. As famílias com mais espécies foram a Leguminosae (41), Cyperaceae (40), Poaceae (38), Orchidaceae (30), Euphorbiaceae (27), Rubiaceae (24), Melastomataceae (21) e Bromeliaceae (20). Foram identificadas espécies comuns a Caatinga, Cerrado, Floresta Estacional, Restinga, entre outras fisionomias, o que corrobora a classificação do local como área de tensão ecológica.

Quanto às áreas de contato e tensão ecológica entre vegetações na área de estudo, destaca-se que entre as regiões costeiras mais úmidas (Mata Atlântica) e as regiões interioranas mais secas (Caatinga) ocorre uma região de transição climática e vegetacional, denominada regionalmente como Agreste. Sem limites físicos, mas representada por uma faixa estreita na direção Norte-Sul, as regiões denominadas de Agreste geralmente coincidem com regiões de transição de vegetação. Apresentam regime de chuvas de até $1.000 \mathrm{~mm}$ por ano e são menos sujeitas às secas catastróficas, uma vez que se beneficiam da umidade residual dos ventos do Sudeste. A vegetação compartilha muitas características e espécies com as expansões semiáridas a Oeste, e apresenta plantas decíduas e espinhosas, bem como cactáceas e bromeliáceas $[16,17]$. São exemplos as espécies lenhosas Schinopsis brasiliensis Engl. (Anacardiaceae), Poincianella pyramidalis (Tul.) L. P. Queiroz (Fabaceae), Aspidosperma pyrifolium Mart. \& Zucc., Tabebuia aurea (Manso) Benth. \& Hook. F. ex S. Moore (Bignoniaceae), Commiphora leptophloeos (Mart.) J. B. Gillett (Burseraceae) e as Cactaceae Pilosocereus gounellei (F. A. C. Weber) Byles \& Rowley e Cereus jamacaru P. DC.

Na região de atuação da Embrapa Tabuleiros Costeiros ocorrem as seguintes áreas de contato ou de tensão ecológica: Savana-Estépica/Floresta Estacional (1.398.196 ha); Floresta Estacional/Savana (839.669 ha); Savana-Estépica/Savana (424.339 ha); Floresta Ombrófila/Campinarana (155.162 ha); Floresta Ombrófila/Savana (153.529 ha); SavanaEstépica/Formação Pioneira (65.801 ha); Floresta Estacional/Savana-Estépica/Savana (49.298 ha); Savana/Formações Pioneiras (46.179 ha); Floresta Ombrófila/Formação Pioneira (31.021 ha); Savana-Estépica/Floresta Ombrófila (191 ha) (Tabela 1 e Figura 3).

\subsubsection{9 Áreas antropizadas e áreas com vegetação natural}

Conforme o mapa de vegetação IBGE (2018) [5], para a região de atuação da Embrapa Tabuleiros Costeiros, excluindo-se as áreas com massa d'água continental, afloramento rochoso, áreas indiscriminadas e áreas com influência urbana, foram mapeados 21.276 .827 ha, com as áreas 
de vegetação distribuídas em dois grandes grupos, o de área antrópica (77\%) e o de vegetação natural (23\%) (Tabela 2 e Figura 4).

Tabela 2: Área total dos tipos de cobertura vegetal em área antrópica e em área de vegetação natural na região de atuação da Embrapa Tabuleiros Costeiros.

\begin{tabular}{lrr}
\hline \multirow{2}{*}{ TIPO DE COBERTURA VEGETAL } & Área total \\
\cline { 2 - 3 } & hectares & $\mathbf{\%}$ \\
\hline ÁREA ANTRÓPICA & $\mathbf{1 6 . 3 8 3 . 1 7 2}$ & $\mathbf{7 7 , 0 0}$ \\
\hline Agropecuária & 7.730 .476 & 36,33 \\
Pecuária (pastagens) & 3.248 .639 & 15,27 \\
Vegetação secundária & 2.137 .813 & 10,05 \\
Agricultura com culturas cíclicas & 1.494 .846 & 7,03 \\
Agricultura com culturas permanentes & 662.206 & 3,11 \\
Agricultura & 215.783 & 1,01 \\
Florestamento/reflorestamento & 893.409 & 4,20 \\
\hline ÁREA DE VEGETAÇÃO NATURAL & $\mathbf{4 . 8 9 3 . 6 5 5}$ & $\mathbf{2 3 , 0 0}$ \\
\hline Floresta Ombrófila Densa & 280.922 & 1,32 \\
Floresta Ombrófila Aberta & 255.980 & 1,20 \\
Floresta Estacional Semidecidual & 312.089 & 1,47 \\
Floresta Estacional Decidual & 32.513 & 0,15 \\
Campinarana Arborizada e Gramíneo-Lenhosa & 18.731 & 0,09 \\
Formação Pioneira com influência fluvial e/ou lacustre & 98.745 & 0,46 \\
Formação Pioneira com influência fluviomarinha & 308.870 & 1,45 \\
Formação Pioneira com influência marinha & 481.990 & 2,27 \\
Savana-Estépica Florestada & 136.421 & 0,64 \\
Savana-Estépica Arborizada & 2.320 .780 & 10,91 \\
Savana-Estépica Parque & 354.895 & 1,67 \\
Savana-Estépica Gramíneo-Lenhosa & 2.394 & 0,01 \\
Savana Florestada & 159 & 0,00 \\
Savana Arborizada & 163.331 & 0,77 \\
Savana Parque & 35.998 & 0,17 \\
Savana Gramíneo-Lenhosa & 9.835 & 0,05 \\
Contato Savana-Estépica/Floresta Estacional & 20.079 & 0,09 \\
Contato Savana-Estépica/Formações Pioneiras & 16.588 & 0,08 \\
Contato Savana-Estépica/Savana & 8.801 & 0,04 \\
Contato Savana/Floresta Estacional & 21.207 & 0,10 \\
Contato Savana/Formações Pioneiras & 13.327 & 0,06 \\
\hline TOTAL = área antrópica + área de vegetação natural & $\mathbf{2 1 . 2 7 6 . 8 2 7}$ & $\mathbf{1 0 0}$ \\
\hline Fonte: IBGE (2018) [5]. & &
\end{tabular}




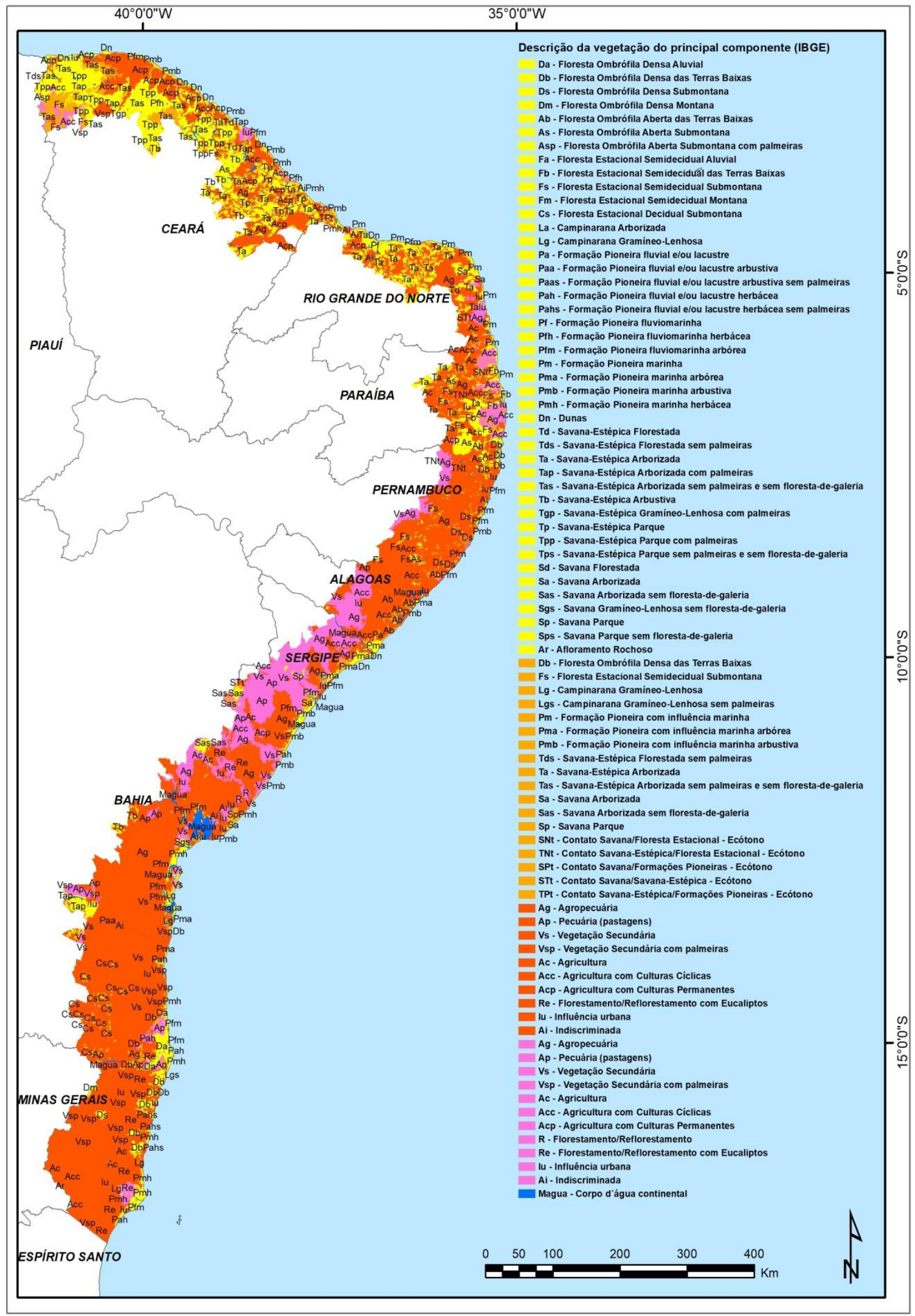

Figura 4: Descrição da vegetação do principal componente na região de atuação da Embrapa Tabuleiros Costeiros. Legendas: amarelo = vegetação natural; laranja = vegetação natural em tensão ecológica; vermelho = área antropizada $;$ rosa = área antropizada em tensão ecológica. Fonte: IBGE (2018) [5].

As áreas antropizadas (77\%) são ocupadas por vegetação secundária (10,05\%) e atividades rurais $(66,95 \%)$, como florestamento/reflorestamento, pecuária (pastagens), agricultura com culturas 
cíclicas ou permanentes e agropecuárias [5] (Tabela 2). A antropização geralmente pode ser enquadrada como de baixo ou alto impacto, e vai desde o extrativismo de produtos vegetais em vegetação secundária, passando por extração seletiva de madeira, desmatamento, queimadas, preparo do solo, cultivo agrícola e de pastagem, chegando até o uso inadequado do solo e a degradação da área. Como resposta à ocorrência diferenciada de clima, geomorfologia, relevo e solos, há grande diversificação de culturas e atividades agrícolas. Destacam-se como principais cultivos pastagem, cana-de-açúcar, mandioca, cítrus, coco, caju, cacau, café, mamão, abacaxi, dendê, fumo, eucalipto, seringueira, dentre outros. Como produtos do extrativismo destacam-se a fibra da piaçava (Attalea funifera Martius), o fruto da mangaba (Hancornia speciosa Gomez), a castanha de caju (Anacardium occidentale L.) e plantas ornamentais.

O IBGE (2018) [5] mapeou 11.254.907 ha (52,11\% da região de atuação da Embrapa Tabuleiros Costeiros) como exclusivamente de Florestas (Ombrófila Densa, Ombrófila Aberta, Estacional Semidecidual e Estacional Decidual) (Tabela 1), das quais sobraram apenas 881.504 ha $(4,14 \%)$ com cobertura de vegetação natural (Tabela 2). Desses quatro tipos florestais, a Floresta Estacional Decidual é a que apresenta menor área de vegetação natural, restando pouco mais de 32 mil hectares, ou 3,13\% da cobertura original. Como apresentado na descrição das fitofisionomias, as Florestas apresentam grande diversidade de espécies vegetais, a qual pode ser drasticamente reduzida conforme a fragmentação dos habitats naturais. Assim, para a região de atuação da Embrapa Tabuleiros Costeiros, as ações de conservação da natureza tanto no âmbito público quanto no privado precisam focar nesses remanescentes de Floresta Estacional Decidual.

Vale destacar que as florestas são ecossistemas importantes na manutenção de serviços ambientais, como produção de água, estoque e sequestro de carbono, regulação do clima, controle de erosão, lazer entre outros [44]. De forma generalizada, a reduzida cobertura florestal nativa nessa região é um fato que deve ser tratado em ações e programas de políticas públicas de conservação da biodiversidade, mudanças climáticas, redução de desmatamento ilegal e regularização ambiental.

\section{CONCLUSÃO}

Mata Atlântica e Caatinga são os dois biomas que abrangem a área de atuação da Embrapa Tabuleiros Costeiros. As fitofisionomias e as respectivas formações vegetais remanescentes identificadas foram: Floresta Ombrófila (Densa e Aberta); Floresta Estacional (Semidecidual e Decidual); Campinarana; Áreas das Formações Pioneiras (vegetação com influência fluvial, fluviomarinha e marinha); Savana-Estépica (Florestada, Arborizada, Parque e Gramíneo-Lenhosa); Savana; e áreas de contato (Floresta Ombrófila/Campinarana; Floresta Ombrófila/Formação Pioneira; Floresta Ombrófila/Savana-Estépica; Floresta Ombrófila/Savana; Floresta Estacional/Savana-Estépica; Floresta Estacional/Savana; Floresta Estacional/SavanaEstépica/Savana; Savana-Estépica/Formações Pioneiras; Savana/Formações Pioneiras; SavanaEstépica/Savana).

Em 2017, as áreas antropizadas na região de atuação da Embrapa Tabuleiros Costeiros chegaram a $77 \%$. Restam apenas $4,14 \%$ de Florestas naturais, importantes para a conservação de diversidade biológica. Nesse contexto, considera-se que pesquisas e políticas públicas, especialmente aquelas relacionadas à regularização ambiental, como no caso do Cadastro Ambiental Rural (CAR), e a fiscalização de desmatamentos irregulares, devem voltar-se para a preservação dos remanescentes de florestas naturais e a recomposição de florestas nativas em áreas estratégicas dentro dos imóveis rurais do CAR. Em termos de pesquisa técnico-científica, o conhecimento sobre a localização e o estado da vegetação natural primária e secundária em áreas de reserva legal e de preservação permanente dos imóveis rurais cadastrados no CAR poderá fornecer informações para o estabelecimento de programas e ações de regularização ambiental na região de atuação da Embrapa Tabuleiros Costeiros, cuja missão é garantir a produção de alimentos em consonância com a sustentabilidade dos biomas. 


\section{AGRADECIMENTOS}

Agradecemos Bibiana Teixeira de Almeida e Vera Viana dos Santos Brandão, analistas da Embrapa Territorial, por revisarem o manuscrito.

\section{REFERÊNCIAS BIBLIOGRÁFICAS}

1. Coutinho, LM. O conceito de bioma. Acta Bot Bras. 2006;20(1):13-23, doi: 10.1590/S010233062006000100002

2. IBGE. Instituto Brasileiro de Geografia e Estatística. Mapa de Biomas do Brasil. 1:5.000.000. Rio de Janeiro: IBGE, 2004. Disponível em: <https://www.ibge.gov.br/geociencias/downloadsgeociencias.html> Acesso em: 30 abr. 2019.

3. IBGE. Instituto Brasileiro de Geografia e Estatística. Mapa de Vegetação do Brasil. 1: 5.000.000. Rio de Janeiro: IBGE, 2004. Disponível em: <https://www.ibge.gov.br/geociencias/downloadsgeociencias.html>. Acesso em: 30 abr. 2019.

4. Cruz MAS, Rocha ROF, Silva AAG, Amorim JRA, Aragão R. GeoTAB: Clima, recursos hídricos e bacias hidrográficas na região de atuação da Embrapa Tabuleiros Costeiros. Sci Plena. 2017;13(10):1-11, doi:10.14808/sci.plena.2017.109914

5. IBGE. Instituto Brasileiro de Geografia e Estatística. Mapa de Vegetação do Brasil. 1: 250.000. Rio de Janeiro: IBGE, 2018. Disponível em: <https://www.ibge.gov.br/geociencias/downloadsgeociencias.html> Acesso em: 30 Abr. 2019.

6. IBGE. Instituto Brasileiro de Geografia e Estatística. Mapa de Biomas do Brasil. 1: 250.000. Rio de Janeiro: IBGE, 2019. Disponível em: <https://www.ibge.gov.br/geociencias/downloadsgeociencias.html> Acesso em: 14 Nov. 2019.

7. Embrapa. Zoneamento Agroecológico do Nordeste do Brasil: diagnóstico e prognóstico. Recife: Embrapa Solos; Petrolina: Embrapa Semiárido; 2000. (Embrapa Solos. Documentos, 14).

8. Dompieri MHG, Resende RS, Barreto AC, Cruz MAS, Silva AAG, Nogueira Junior LR, Ivo WMPM, Silva MAS, Cuenca MAG, Fernandes MF. Delimitação da área foco de atuação da Embrapa Tabuleiros Costeiros e principais aspectos fisiográficos. Aracaju: Embrapa Tabuleiros Costeiros; 2015. 41 p. (Embrapa Tabuleiros Costeiros. Documentos, 194).

9. Jacomine PKT. Evolução do conhecimento sobre solos coesos no Brasil. In: Anais do 2 Workshop Coesão em Solos dos Tabuleiros Costeiros, 2001; Aracaju: Embrapa Tabuleiros Costeiros, 2001. p.19-46,

10. IBGE. Instituto Brasileiro de Geografia e Estatística. Manual Técnico da Vegetação Brasileira. Rio de Janeiro: IBGE, 2012. Disponível em: 〈https://biblioteca.ibge.gov.br/visualizacao/livros/liv63011.pdf〉. Acesso em: 30 abr. 2019.

11. Myers N, Mittermeier RA, Mittermeier CG, Fonseca GAB, Kent J. Biodiversity hotspots for conservation priorities. Nature. 2000;(403):853-858, doi:10.1038/35002501

12. Ministério do Meio Ambiente. Disponível em: <http://www.mma.gov.br/images/imagens/responsabilidade_socioambiental/a3p/FolderAlterado_copy.png>. Acesso em: 30 abr. 2019.

13. Fundação SOS Mata Atlântica; INPE. Atlas dos remanescentes florestais da Mata Atlântica período 20162017: relatório final. São Paulo: Fundação SOS Mata Atlântica, 2018. 63p .

14. Thomas WW, Carvalho AMV, Amorim AM, Garrison J, Arbeláez AL. Plant endemism in two forests in southern Bahia, Brazil. Biodivers Conserv. 1998;7(3):311-322, doi: 10.1023/A:1008825627656

15. Ostroski P, Saiter FZ, Amorim AM, Fiaschi P. Endemic angiosperms in Bahia Coastal Forests, Brazil: an update using a newly delimited area. Biota Neotr. 2018;18(4):1-14, doi: 10.1590/1676-0611-bn-20180544

16. Leal IR, Tabarelli M, Silva JMC da. Ecologia e conservação da caatinga. Recife: Ed. Universitária da UFPE; 2003. $822 \mathrm{p}$.

17. Silva JMC da, Tabarelli M, Fonseca MT da, Lins LV. Biodiversidade da Caatinga: áreas e ações prioritárias para a conservação. Brasília, DF: Ministério do Meio Ambiente: Universidade Federal de Pernambuco; 2003. $382 \mathrm{p}$.

18. ICMBIO. Instituto Chico Mendes de Conservação da Biodiversidade. Plano de Manejo Parque Nacional do Pau Brasil: volume 1. Brasília: Ministério do Meio Ambiente; 2016. 301 p.

19. RPPN Estação Veracel. Plano de Manejo. Eunápolis: Veracel Celulose, gerência de sustentabilidade, e conservação internacional, 2016. 100 p.

20. Amorim AM, Jardim JG, Lopes MMM, Fiaschi P, Borges RAX, Perdiz RO, Thomas WW. Angiosperms of Montane Forest areas in southern Bahia, Brazil. Biota Neotr. 2009;9(3):313-348, doi:10.1590/S167606032009000300028 
21. Thomas WW, Barbosa MRV. Natural Vegetation Types in the Atlantic Coastal Forest of Northeastern Brazil. In: Thomas WW editor. The Atlantic Coastal Forests of Northeastern Brazil. Mem New York Bot Gard. 2008a;100:6-20.

22. Thomas WW, Carvalho AMV, Amorim AM, Garrison J, Santos TS. Diversity of woody plants in the Atlantic coastal forest of southern Bahia, Brazil. In: Thomas WW editor. The Atlantic Coastal Forests of Northeastern Brazil. Mem New York Bot Gard. 2008b;100:21-66.

23. Copener Florestal. Plano de Manejo da RPPN Lontra. Itanagra/Entre Rios: Copener Florestal; 2016. 297 p.

24. Landim MF, Sales AB, Matos IS, Proença CEB. Floristic characterization of an Atlantic Rainforest remnant in Southern Sergipe: Crasto forest. Biota Neotr. 2015;15(1):1-16, doi:10.1590/167606032014003613

25. Rocha KD, Chaves LFC, Marangon LC, Lins E Silva ACB. Caracterização da vegetação arbórea adulta em um fragmento de floresta atlântica, Igarassu, PE. Rev Bras Ci Agr. 2008;3(1):35-41, doi: 10.5039/agraria.v3i1a219

26. Machado MABL, Chaves LFC, Rosa Neto JL, Lemos RPL. Florística do estrato arbóreo de fragmentos da mata atlântica do nordeste oriental, município de Coruripe, Alagoas, Brasil. Rev Ouricuri. 2012;2(2):55-72.

27. ICMBIO. Instituto Chico Mendes de Conservação da Biodiversidade. Plano de Manejo Estação Ecológica de Murici: Diagnóstico. Brasília: Ministério do Meio Ambiente; 2017. 184 p.

28. Thomas WW, Jardim JG, Fiaschi P, Mariano Neto E, Amorim AM. Composição florística e estrutura do componente arbóreo de uma área transicional de Floresta Atlântica no sul da Bahia, Brasil. Rev Bras Bot. 2009;32(1):65-78, doi:10.1590/S0100-84042009000100007

29. Rodal MJN, Barbosa MRV, Thomas WW. Do the seasonal forests in northeastern Brazil represent a single floristic unit? Braz J Biol. 2008;68(3):467-475, doi:10.1590/S1519-69842008000300003

30. Alves M, Oliveira RB, Teixeira SR, Guedes MLS, Roque N. Levantamento florístico de um remanescente de Mata Atlântica no litoral norte do Estado da Bahia, Brasil. Hoehnea. 2015;42(3):581-595, doi:10.1590/2236-8906-06/2015

31. Ibama. Instituto Brasileiro do Meio Ambiente e dos Recursos Naturais. Plano de Manejo Reserva Biológica Guaribas. Brasília: Ministério do Meio Ambiente; 2003. 825p.

32. Costa-Lima JL da, Alves M. Flora da Reserva Biológica Guaribas, Estado da Paraíba, Brasil: Erythroxylaceae. Hoehnea. 2018;45(3):1-7, doi:10.1590/2236-8906-84/2017

33. Soares Filho A de O. Fitogeografia e estrutura das florestas estacionais deciduais no Brasil. [tese]. Feira de Santana (BA): Universidade Estadual de Feira de Santana; 2012. 346 p.

34. Meira Neto JAA, Souza AL de, Lana JM de, Valente GE. Composição florística, espectro biológico e fitofisionomia da vegetação de muçununga nos municípios de Caravelas e Mucuri, Bahia. Rev Árvore. 2005;29(1):139-150, doi:10.1590/S0100-67622005000100015.

35. Saporetti Junior AW. Vegetação e solos de Muçununga em Caravelas, Bahia. [tese]. Viçosa (MG): Universidade Federal de Viçosa; 2009. 127 p.

36. Brito CR. Mapeamento de Muçunungas no sul da Bahia e norte do Espírito Santo utilizando técnicas de sensoriamento remoto. [dissertação]. Viçosa (MG): Universidade Federal de Viçosa; 2012.127 p.

37. Saporetti Junior AW, Schaefer CEGR, de Souza AL, Soares MP, Araújo DSD, Meira-Neto JAA. Influence of Soil Physical Properties on Plants of the Mussununga Ecosystem, Brazil. Folia Geobot. 2012;47(1):29-39, doi:10.1007/s12224-011-9106-9.

38. Zickel CS, Vicente A, Almeida Junior EB, Cantarelli JRR, Sacramento AC. Flora e vegetação das restingas no Nordeste Brasileiro. In: Eskinazi-Leça E, Neumann-Leitão S, Costa MF, editors. Oceanografia: um cenário tropical. Recife: Bargaço; 2004. p. 689-701.

39. Cantarelli JRR, Almeida Junior EB de, Santos Filho FS, Zickel CS. Tipos fitofisionômicos e florística da restinga da APA de Guadalupe, Pernambuco, Brasil. INSULA Rev Bot. 2012;(41):95-117, doi:10.5007/2178-4574.2012n41p95 .

40. Costa GM da, Pereira J de S, Martins MLL, Aona LYS. Florística em fitofisionomias de restinga na Bahia, nordeste do Brasil. Rev Biol Neotrop. 2018;15(2):78-95, doi:10.5216/rbn.v15i2.53845.

41. Cuzzuol GRF, Campos A. Aspectos nutricionais na vegetação de manguezal do estuário do Rio Mucuri, Bahia, Brasil. Rev Bras Bot. 2001;24(2):227-234, doi:10.1590/S0100-84042001000200013

42. Reis ATCC. Comparação florística e diversidade das áreas core de savanas "Cerrado" e disjunções do leste da Bahia, Brasil. [tese]. Feira de Santana: Universidade Estadual de Feira de Santana; 2014. 266 p.

43. Mendes K, Gomes P, Alves M. Floristic inventory of a zone of ecological tension in the Atlantic Forest of Northeastern Brazil. Rodriguésia. 2010;61(4):669-676.

44. Costanza R, D’Arge R, de Groot RS, Farber S, Grasso M, Hannon B, Limburg K, Naeem S, O’Neill RV, Paruelo J, Raskin RG, Sutton P, Van Den Belt M. The value of the world's ecosystem services and natural capital. Nature. 1997;(387):253-260, doi:10.1038/387253a0 